\title{
ANALISA PENERAPAN STANDAR AKUNTANSI KEUANGAN ENTITAS MIKRO KECIL DAN MENENGAH (SAK EMKM) PADA LAPORAN KEUANGAN SKATERS SHOP DISTRO
}

\author{
Tasum \\ Fakultas Ekonomi Universitas Krisnadwipayana \\ Jalan Unkris Jatiwaringin Jakarta Timur
}

\begin{abstract}
This study examines Micro, Small and Medium Entity Financial Accounting Standards (MSME) Skaters Shop Distros. The population in this study is the recapitulation of recording cash disbursements, cash receipts, and merchandise inventory Skaters Shop Distro. The sampling technique in this study uses non probability sampling with purposive sampling technique. In this study, the data or information obtained by the author were analyzed qualitatively with a descriptive approach. The result of this study is that the understanding of Skaters Shop Distro owners about Micro, Small and Medium Entity Financial Accounting Standards (SAK EMKM) is still very low. Recording and preparing financial statements is still very simple and in accordance with the needs and understanding of the owner. Skaters Shop Distro has not applied the Financial Accounting Standards for Micro, Small and Medium Enterprises (SAK EMKM) because they still do not understand about SAK EMKM and its limited time and human resources.
\end{abstract}

Keywords: Financial Accounting Standards for Micro, Small and Medium Enterprises (SAK EMKM), and Financial Statement

\section{PENDAHULUAN}

Wirausaha memiliki peran
penting dalam meningkatkan
kesejahteraan masyarakat. Wirausaha
dapat membuat masyarakat menjadi
mandiri dan memiliki penghasilan
sendiri tanpa harus menggantungkan
harapan kepada perusahaan orang lain
yang bisa kapan saja diberhentikan
dengan alasan tertentu. Wirausaha juga
dapat membuka peluang untuk diri
sendiri maupun orang lain dan dapat
menarik keuntungan dari peluang yang
diciptakan tersebut. Karena pada
dasarnya setiap usaha didirikan
bertujuan untuk memperoleh
keuntungan ataupun tujuan tertentu,
dimana tujuan masing-masing usaha

secara umum dapat dikatakan sama, hanya prioritas nya yang berbeda.

Usaha Mikro, Kecil, dan Menengah (UMKM) merupakan bagian penting dalam kehidupan perekonomian suatu negara dan sangat memberikan kontribusi dalam meningkatkan kesejahteraan masyarakat khusunya di negara-negara yang jumlah penduduknya padat seperti Indonesia. Selain itu UMKM dapat berguna untuk menciptakan lapangan kerja dan pendapatan yang cukup besar bagi masyarakat Indonesia sehingga dapat mengurangi salah satu permasalahan yang dihadapi Indonesia yaitu pengangguran.

Informasi akuntansi mempunyai salah satu peran penting untuk

Copyright (c) 2020 Tasum Tasum SE., M.Si 
mencapai keberhasilan suatu usaha, termasuk usaha kecil. Tetapi dalam kenyataanya, kebanyakan pengusaha kecil di Indonesia tidak menyelenggarakan dan menggunakan akuntansi dalam pengelolaan usahanya. Pengusaha kecil memandang bahwa proses akuntansi tidak terlalu penting untuk diterapkan dalam usahanya. Penerapan ilmu akuntansi dalam pengelolaan keuangan UMKM dinilai masih kurang dipahami oleh para pengusaha. Masih banyak pengusaha kecil yang belum melakukan pencatatan terhadap laporan keuangan usahanya dengan baik. Bahkan, masih ada yang tidak melakukan pencatatan. Para pengusaha kecil dan menengah biasanya hanya melakukan pembukuan sebatas pencatatan pendapatan dan pengeluaran saja.

Skaters Shop Distro merupakan usaha kecil yang bergerak dibidang perdagangan distro, memiliki kendala dalam sistem pencatatan yang dilakukannya sangat sederhana yang belum sesuai dengan Standar Akuntansi Keuangan Entitas Mikro, Kecil dan Menengah (SAK EMKM) yang berlaku. Salah satu alasan tidak adanya catatan akuntansi yang memadai pada Skaters Shop, karena Skaters Shop menganggap bahwa manfaat atas informasi akuntansi yang dihasilkan lebih kecil dibandingkan biaya yang harus mereka korbankan ketika mereka menyelenggarakan praktik akuntansi secara tepat. Namun pada kenyataan yang sesungguhnya Skaters Shop sangat menginginkan adanya laporan keuangan pada tokonya yang sesuai dengan Standar Akuntansi Keuangan Entitas Mikro, Kecil dan Menengah (SAK EMKM) agar dapat membantu Skaters Shop mengoptimalkan kinerjanya, khususnya bisa mengembangkan bisnisnyaa dari sumber pendanaan. Skaters Shop hanya melakukan pencatatan pemasukan dan pengeluaran kas, dan mencatat persediaan barang dagang selama satu periode. Pencatatan pemasukan dan pengeluaran kas dilakukan untuk mengetahui berapa keuntungan yang didapat.

Rendahnya

pendidikan, kurangnya pemahaman dan sosialisasi mengenai administrasi keuangan yang sesuai standar membuat penyusunan laporan keuangan Skaters Shop tidak Sesuai berdasarkan SAK EMKM yang berlaku dan laporan keuangan tidak dapat dipertanggungjawabkan sehingga pencatatan kurang akurat. Ikatan Akuntan Indonesia (IAI) mengeluarkan SAK EMKM yang dirancang sebagai standar akuntansi sederhana dibandingkan dengan Standar Akuntansi Keuangan Entitas Tanpa Akuntabilitas Publik (SAK ETAP). SAK EMKM berlaku efektif per 1 Januari 2018 dengan penerapan dini diperkenankan pernyataan tersebut dikutip dalam laman Ikatan Akuntansi Indonesia di website iaiglobal.or.id. Berdasarkan uraian tersebut maka yang menjadi permasalahan dalam penelitian ini adalah sebagai berikut:

1. Bagaimana penerapan laporan keuangan pada Skaters Shop Distro?

2. Apakah penerapan laporan keuangan pada Skaters Shop Distro sesuai dengan Standar Akuntansi Keuangan Entitas Mikro, Kecil dan Menengah (SAK EMKM)? 


\section{LANDASAN TEORI}

\section{Laporan Keuangan}

Laporan keuangan adalah laporan pertanggungjawaban manager atau pimpinan perusahaan atas pengelolaan perusahaan yang dipercayakan kepadanya kepada pihak-pihak luar perusahaan. Wahyudiono (2014: 10). Sedangkan menurut Wardiya (2017: 5) Laporan keuangan adalah laporan tertulis yang merupakan bentuk pandangan secara wajar mengenai posisi keuangan, kinerja, dan arus kas perusahaan yang bermanfaat bagi kalangan pengguna laporan dalam rangka membuat keputusan ekonomi serta menunjukkan pertanggungjawaban manajemen atas penggunaan sumber daya yang ada.

\section{Tujuan Laporan Keuangan}

Menurut (Hery 2017) Tujuan keseluruhan dari pelaporan keuangan adalah untuk memberikan informasi yang berguna bagi investor dan kreditur dalam pengambilan keputusan investasi dan kredit. Sedangkan menurut IAI dalam PSAK No. 1 Tahun 2017 Revisi Tahun 2015 paragraf 09 (Ikatan Akuntansi Indonesia, 2017) mengemukakan tujuan laporan keuangan adalah memberikan informasi mengenai posisi keuangan, kinerja keuangan, dan arus kas entitas yang bermanfaat bagi sebagian besar kalangan pengguna laporan keuangan dalam pembuatan keputusan.

\section{Usaha Mikro Kecil dan Menengah (UMKM)}

Entitas Mikro, Kecil dan Menengah yaitu entitas tanpa akuntabilitas publik yang signifikan, sebagaimana didefinisikan dalam SAK ETAP, yang memenuhi definisi dan kriteria usaha mikro, kecil, dan menengah sebagaimana diatur dalam peraturan perundang-undangan yang berlaku di Indonesia, setidaktidaknya selama dua tahun berturut-turut, SAK EMKM (2016: 2). Menurut Nayla (2014) UMKM merupakan jenis usaha yang didirikan secara pribadi dan memiliki jumlah kekayaan sebesar Rp 200.000.000 (dua ratus juta rupiah) jumlah tersebut tidak termasuk tanah dan bangunan.

\section{Standar Akuntansi Keuangan Entitas Mikro Kecil dan Menengah (SAK EMKM)}

Menurut Ikatan Akuntan Indonesia (2018) ED SAK EMKM disusun untuk memenuhi kebutuhan pelaporan keuangan entitas mikro, kecil, dan menengah dalam menyusun laporan keuangan. Standar ini digunakan oleh entitas yang tidak memiliki akuntabilitas publik signifikan. Undang-Undang No 20 Tahun 2008 tentang Usaha Mikro, Kecil, dan Menengah dapat digunakan sebagai acuan dalam mendefinisikan dan memberikan rentang kuantitatif EMKM. ED SAK EMKM ditujukan untuk digunakan oleh entitas yang tidak atau belum mampu memenuhi persyaratan akuntansi yang diatur dalam SAK ETAP. Industri mikro, kecil dan menengah dapat menerapkan 
SAK EMKM mulai efektif per tanggal 1 Januari 2018 dan penerapan dini dianjurkan.

\section{Kerangka Konseptual}

Gambar1. Kerangka Konseptual

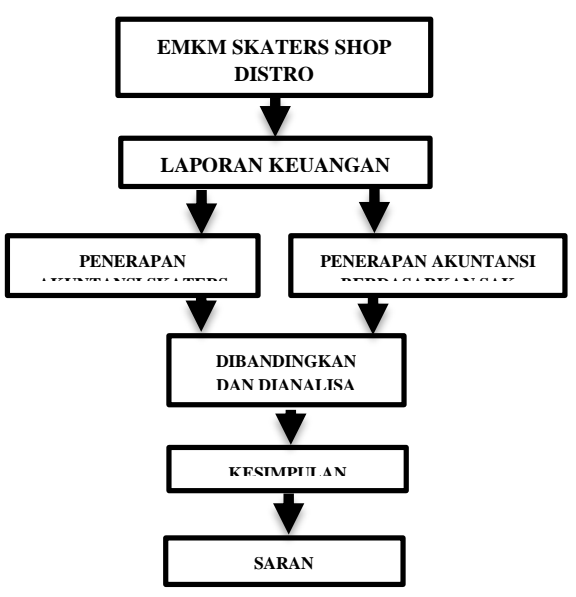

\section{METODE PENELITIAN}

Objek dari penelitian ini adalah UMKM Skaters Shop Distro yang berlokasi di Jl.Raya Abdul Gani No.22 Kalibaru, Kec. Cilodong, Kota Depok. Populasi dalam penelitian ini adalah rekapitulasi pencatatan pengeluaran kas, pemasukan kas, dan persediaan barang dagang Skaters Shop Distro. Teknik pengambilan sampel dalam penelitian ini menggunakan non probability sampling dengan teknik purposive sampling. Pada penelitian ini, data atau informasi yang diperoleh penulis dianalisis secara kualitatif dengan pendekatan yang bersifat deskriptif.

\section{HASILPENELITIAN PEMBAHASAN}

Skaters Shop Distro merupakan sebuah distro yang berdiri pada tahun
2010. Skaters Shop distro didirikan berdasarkan perkembangan gaya busana remaja di Jakarta yang saat ini sedang populer. Peluang usaha celana jeans merupakan salah satu bisnis yang memiliki segmen pasar yang cukup jelas dan termasuk fanatik. Meskipun bisnis di dunia fashion termasuk yang paling ketat persaingannya, namun seiring dengan perkembangan teknologi yang semakin canggih dan jelang era pasar bebas membuat peluang usaha celana jeans tak pernah mati.

Skaters Shop distro didirikan oleh dua orang sahabat yaitu Martias dan Bobby dua orang sahabat yang memiliki visi dan misi yang sama untuk membangun suatu usaha yang diberi nama Skaters Shop diawali dengan sistem pemasaran dari mulut ke mulut dan selama satu Tahun pertama distro ini dibuka pemilik tidak mengambil keuntungan dan hanya mencari nama terlebih dahulu kemudian dengan berjalannya waktu Skaters Shop Distro mengalami peningkatan permintaan dari konsumen.

Kegiatan Skaters Shop yang terlibat dalam penjualan barang secara langsung kepada konsumen akhir untuk penggunaan pribadi. Target pasar Skaters Shop distro adalah kaula muda baik pria maupun wanita. Kota Depok memiliki peluang yang sangat besar untuk usaha karena sangat ramai penduduk dan tentunya akan banyak dikunjungi oleh berbagai kalangan mahasiswa dan masyarakat setempat. Kisaran harga yang dijual pun memiliki harga standar untuk semua produk. Skaters Shop Distro juga mempunyai halaman parkir yang luas

Copyright (c) 2020 Tasum Tasum SE., M.Si 
dan lokasi yang strategis berada di depan jalan raya yang membuat seluruh orang lewat akan melihat bahwa ada distro disana kemudian mereka tertarik untuk mampir.

\section{Laporan Keuangan Skaters Shop Distro}

Berdasarkan Undang-Undang N0 20 Tahun 2008 tentang usaha, mikro, kecil, dan menengah. Skaters Shop Distro merupakan usaha kecil yang termasuk kedalam entitas mikro kecil, yang dimaksud usaha mikro kecil usaha produktif milik orang perorangan atau badan usaha perorangan yang memenuhi kriteria usaha mikro kecil. Penyusunan laporan keuangan Skaters Shop Distro belum menerapkan sebagaimana yang disebutkan dalam SAK EMKM. Pencatatan laporan keuangan yang disajikan di Skaters Shop Distro masih sangat sederhana dan manual. Skaters Shop Distro belum membuat kebijakan, pengakuan, penyajian, pengukuran, dan pelaporan pada laporan keuangan. Pencatatan hanya menyajikan rekapitulasi pemasukan dan pengeluaran kas yang dicatat dari bulan Januari sampai Desember. Rekapitulasi pemasukan dan pengeluaran kas dicatat setiap ada transaksi yang terjadi lalu dibuat laporan keuangan terdiri dari laporan bulanan, laporan tahunan, laporan pembelian dan laporan persediaan barang dagang diakhir tahun. Laporan bulanan Skaters Shop Distro terdiri dari rekapitulasi pemasukan kas yaitu penjualan barang dagang yang dicatat mulai dari omset, modal pokok, laba kotor, dan pengeluaran kas terdiri dari biaya operasional. Laporan keuangan tahunan dicatat dari total rekapitulasi pemasukan dan pengeluaran kas bulanan yang terdiri dari jumlah omset, harga pokok, dan laba bersih setiap bulan, keseluruhan ditotal maka akan diketahui jumlah omset, harga pokok, dan laba bersih.

Skaters Shop Distro tidak melakukan pencatatan persediaan barang dagang yang tersedia di toko setiap hari karena tidak ada waktu. Pencatatan persediaannya dihitung pada akhir tahun untuk mengetahui total keseluruhan persediaan barang dagang pada akhir periode dan mencocokan harga pokok penjualan yang terjadi selama satu tahun. Penghitungan persediaan barang di akhir tahun tujuannya untuk mengetahui apakah barang dagang mengalami peningkatan dari awal tahun atau sebaliknya. Jika terdapat perbandingan persediaan barang dagang diakhir tahun dengan catatan yang sudah ada tetapi belum dihitung maka Skaters Shop Distro menilai perbandingan tersebut sebagai beban barang dagang yang hilang atau kesalahan dalam pencatatan harga pokok penjualan yang keliru pada saat karyawan melakukan pencatatan dilaporan bulanan. Akuntansi menilai pencatatan persediaan setiap pada awal dan akhir periode disebut metode periodik, dimana pencatatan persediaan dilakukan untuk menentukan harga pokok penjualan yang nantinya akan dicatat dalam laporan laba rugi. Penghitungan dalam menentukan harga pokok penjualan atau biaya perolehan persediaan Skaters Shop Distro tidak menggunakan metode FIFO (first in first out) dan average. Dan teknik 
pengukuran biaya persediaan Skaters Shop Distro tidak menggunakan metode eceran. Metode penghitungan persediaan akhir barang dagang dilakukan dimana persediaan ditandai satu persatu dengan harga pokok penjualan.

Kemudian mengelompokkan unit produk pada harga pokok penjualan yang sama, lalu menjumlahkan seluruh produk yang tersisa pada akhir periode berdasarkan pada harga pokok penjualan produk per unit pada saat pembelian barang dagang. Dengan demikian maka Skaters Shop Distro dapat mengetahui total keseluruhan persediaan barang dagang atau biaya perolehan barang akhir periode yang berada di toko.

Didalam SAK EMKM teknik pengukuran biaya persediaan bisa menggunakan metode eceran dan penghitungan harga pokok penjualan atau biaya perolehan persediaan bisa memilih dengan menggunakan rumus FIFO dan average. Hal diatas jelas belum sesuai dengan SAK EMKM yang mengatur bahwa setiap entitas harus menyajikan tiga komponen laporan keuangan yang terdiri dari laporan posisi keuangan, laporan laba rugi, dan catatan atas laporan keuangan. Siklus akuntansi adalah urutan kerja yang harus dilakukan oleh akuntan sejak awal hingga menghasilkan laporan keuangan. Dalam kesehariannya proses sistem pencatatan yang dilakukan oleh Skaters Shop Distro adalah sebagai berikut :

1. Mengumpulkan bukti-bukti transaksi dari transaksi pengeluaran dan pemasukan.

2. Setiap transaksi keuangan yang terjadi, pemilik mencatatnya dalam laporan pembukuannya secara manual.

3. Membuat laporan pembukuan bulanan dan tahunan.

Gambar 2. Siklus Pencatatan Skaters Shop Distro

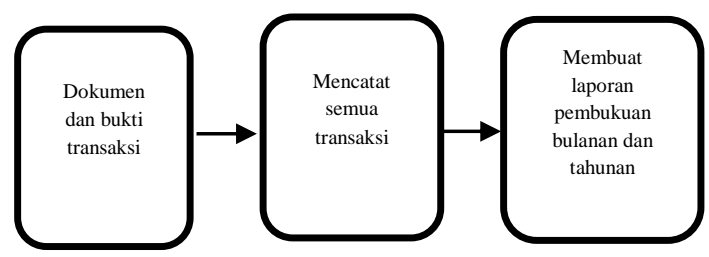

Gambar 2 menjelaskan proses penyusunan laporan keuangan yang ada di Skaters Shop Distro. Pemilik mengetahui bahwa laporan pembukuan sangatlah penting untuk mengetahui berapa keuntungan yang diperoleh. Berdasarkan hasil penelitian, laporan keuangan Skaters Shop Distro terdiri dari transaski pemasukan dan pengeluaran dan pencatatan bebanbeban seperti gaji, beban listrik, telepon dan lain lain. Dalam SAK EMKM ada beberapa ketentuan yang dapat dipergunakan sebagai pedoman untuk menyususn laporan keuangan Skaters Shop Distro. Laporan keuangan Skaters Shop Distro Belum adanya pemisahan antara aset lancar, aset tidak lancar, dan kewajiban jangka panjang maupun jangka pendek dalam laporan posisi keuangan.

Laporan keuangan Skaters Shop Distro belum adanya pemisahan antara pendapatan dan beban dalam laporan keuangannya. Sedangkan dalam SAK EMKM menjelaskan bahwa dalam dalam laporan posisi keuangan harus adanya pemisahan antara aset lancar, aset tidak lancar, liabilitas, dan ekuitas. Sedangkan dalam laporan laba rugi harus adanya pemisahan pendapatan,

Copyright (c) 2020 Tasum Tasum SE., M.Si 
beban, dan pajak penghasilan. Terkait dengan siklus pencatatan yang sesuai dengan akuntansi adalah mulai dari transaksi, jurnal, buku besar, neraca saldo, neraca lajur, dan yang terakhir adalah laporan keuangan.

Gambar 3. Siklus Akuntansi

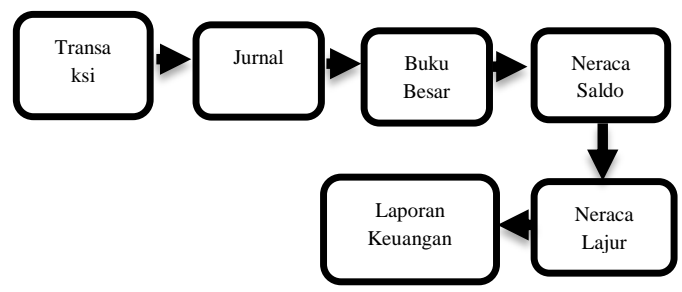

Pencatatan dan pembuatan laporan keuangan masih belum sesuai dengan ilmu akuntansi, karena pencatatan yang dilakukan tidak menunjukan tahaptahap seperti yang ada pada siklus akuntansi dan pencatatan hanya dapat dipahami oleh pemilik Skaters Shop itu sendiri. Pencatatan keuangan seharusnya dapat memberikan informasi keuangan perusahaan sehingga pencatatan harus memiliki karakteristik mudah dipahami, relevan, dan akurat

Pencatatan yang dilakukan oleh Skaters Shop juga tidak menunjukan hasil yang akurat, karena karyawan tidak melakukan pencatatan secara rutin dan keuangannya masih tercampur dengan uang pribadi.

\section{Produk Skaters Shop Distro}

Produk yang dijual oleh Skaters Shop Distro merupakan produk fashion dimana produk tersebut meliputi :

1. T-sihrt (kaos)

2. Jeans (celana)

3. Jacket (jaket)

Produk yang dijual Skaters Shop Distro memiliki brand seperti Decley
Premium, Up Grade, Hermes, Armani Exchange, Prada, Qiudong'ji, G-Rock. Produk dari Skaters Shop Distro selalu mencoba untuk menyesuaikan dengan desain yang sedang menjadi trend pada saat ini.

\section{Transaksi Yang Terjadi}

Transaksi yang terjadi pada Skaters Shop Distro yaitu transaksi penjualan barang dagang secara tunai, pembelian barang dagang secara tunai, pembayaran distribusi toko berupa uang keamanan dan kebersihan, pengeluaran upah angkut, bensin saat belanja barang dagangan, pembelian mesin kasir, pembelian plastik dan perlengkapan lainnya, pembayaran biaya listrik, air, wifi, pulsa handphone toko, pembayaran gaji karyawan, dan pembayaran sewa toko.

\section{Pembahasan Hasil Penelitian}

Analisa Laporan Keuangan Skaters Shop Distro Berdasarkan Kebijakan Akuntansi Menurut SAK EMKM

1. Kebijakan Akuntansi, Estimasi, dan Kesalahan

SAK EMKM menjelaskan panduan untuk memiliki dan menerapkan kebijakan akuntansi yang digunakan dalam menyusun laporan keuangan, mengatur perlakuan akuntansi jika terdapat perubahan estimasi akuntansi dan koreksi kesalahan periode lalu.

a. Kebijakan Akuntansi

kebijakan akuntansi adalah prinsip, dasar, konvensi, aturan, dan praktik tertentu yang diterapkan oleh entitas dalam

Copyright (c) 2020 Tasum Tasum SE., M.Si 
menyusun dan menyajikan laporan keuangan. jika SAK EMKM secara spesifik mengatur perlakuan transaksi atas suatu transaksi, peristiwa atau keadaan lainya maka entitas menerapkan kebijakan akuntansi sesuai dengan pengaturan yang ada dalam SAK EMKM ini.

b. Konsistensi

Kebijakan

Akuntansi

SAK EMKM menjelaskan bahwa entitas memilih dan menerapkan kebijakan akuntansinya secara konsisten untuk transaksi, peristiwa, dan kondisi lain yang serupa.

c. Perubahan

Kebijakan

Akuntansi

SAK EMKM menjelaskan bahwa entitas mengubah kebijakan akuntansinya jika perubahan :

1. Disyaratkan berubah sesuai dengan SAK EMKM.

2. Akan menghasilkan laporan keuangan yang menyediakan informasi yang andal dan lebih relevan mengenai pengaruh transaksi, peristiwa, dan kondisi lain terhadap posisi keuangan atau kinerja keuangan.

d. Koreksi Kesalahan Periode Lalu

SAK EMKM menjelaskan bahwa kesalahan periode lalu adalah kelalaian dan kesalahan pencatatan dalam laporan keuangan entitas untuk satu atau lebih periode lalu yang muncul dari kegagalan untuk menggunakan atau kesalahan pengguna informasi yang andal:

1. Yang tersedia ketika laporan keuangan diterbitkan.

2. Yang selayaknya diperoleh dan dipertimbangkan dalam penyusunan dan penyajian laporan keuangan tersebut.

kesalahan tersebut termaksud dampak kesalahan matematis, kesalahan penerapan kebijakan akuntansi, kekeliruan, atau kesalahan interprestasi, fakta, dan kecurangan.

SAK EMKM menjelaskan bahwa entitas mengoreksi kesalahan periode lalu secara retrospektif pada laporan keuangan yang diterbitkan pertama kali setelah penemuan dengan cara :

1. Menyajikan kembali jumlah komparatif untuk periode penyajian sebelumnya dimana kesalahan terjadi.

2. Jika kesalahan terjadi sebelum periode penyajian paling awal, maka saldo awal aset, liabilitas, dan ekuitas periode penyajian paling awal disajikan kembali.

2. Laporan Posisi Keuangan

a. Aset

1 Pengakuan

Skaters Shop Distro mengakui aset ketika entitas menjadi salah satu pihak dalam kontraktual aset keuangan tersebut. Pengakuan atas transaksi kas, persediaan barang 
dagang, perlengkapan, sewa dibayar dimuka yang dilakukan oleh Skaters Shop Distro diakui sebagai aset lancar dan dicatat sebesar nominalnya. Untuk akun sewa dibayar dimuka, akun tersebut muncul pada saat peneliti membuat ayat jurnal penyesuaian. Sebelumnya, akun tersebut dicatat oleh penjual sebagai beban sewa toko selama satu tahun yang dibebankan di bulan Desember saja. Di dalam SAK EMKM entitas menerapkan kriteria pengakuan dalam menentukan pengakuan aset tetap. Entitas mengakui suatu pengeluaran sebagai biaya perolehan aset tetap jika manfaat ekonomik dapat dipastikan mengalir ke dalam atau dari entitas dan biaya dapat diukur secara andal. Peralatan dan akumulasi penyusutan diakui sebagai aset tetap yang dicatat sebesar nominalnya.

2 Pengukuran

Akun kas di dalam rekapitulasi pencatatan dan pengeluaran kas Skaters Shop Distro diukur dari saldo tunai yang dimiliki di setiap akhir tahun tepatnya per 31 Desember. Pencatatan kas dilakukan pada saat penerimaan dan pengeluaran kas. Persediaan akhir diukur dimana persediaan ditandai satu persatu dengan harga pokok penjualan. Kemudian mengkelompokan unit produk pada harga pokok penjualan, lalu menjumlahkan seluruh produk yang tersisa pada akhir periode berdasarkan pada harga pokok penjualan produk per unit pada saat pembelian barang dagang. Dengan demikian maka Skaters Shop Distro dapat mengetahui total keseluruhan persediaan barang dagang pada akhir periode yang berada di toko.

Pengukuran persediaan dalam Skaters Shop Distro belum sesuai standar di dalam SAK EMKM dalam hal pengukuran persediaan, agar lebih memudahkan perhitungannya dapat menggunakan metode eceran agar hasilnya mendekati biaya perolehan. Metode ini didasarkan atas konsep adanya hubungan yang dekat dan konstan antara harga perolehan barang dengan harga jualnya. Langkah-langkah untuk menentukan nilai persediaan adalah menetapkan harga eceran atau harga jual, menetapkan rasio atau perbandingan antara harga perolehan barang yang tersedia untuk dijual dengan harga ecerannya, 
menetapkan persediaan akhir menurut harga eceran yaitu barang yang tersedia untuk dijual menurut harga eceran dikurangi penjualan, menetapkan nilai persediaan berdasarkan prosentase rasio harga perolehan terhadap harga eceran. Pada saat memperoleh aset, biaya perolehan aset diukur pada harga transaksi (transaction price) dan terdapat biaya yang terkait langsung dengan perolehan aset disebut sebagai biaya transaksi, dimana diakui sebagai beban didalam laporan laba rugi. Aset tetap diukur berdasarkan biaya perolehan dikurangi akumulasi penyusutan dengan menggunakan metode garis lurus tanpa memperhitungkan nilai residu. Umur manfaat aset ditentukan berdasarkan periode kegunaan yang diperkirakan oleh entitas.

3 Penyajian

Kas, persediaan barang dagang, perlengkapan, sewa dibayar dimuka, peralatan, dan akumulasi penyusutan peralatan disajikan dalam laporan posisi keuangan dalam kelompok aset.

b. Liabilitas

\section{Pengakuan}

Skaters Shop Distro dalam kegiatan usahanya menjual dan membeli barang dagang secara tunai, maka tidak muncul akun liabilitas dalam laporan posisi keuangannya. Entitas mengakui liabilitas ketika entitas menjadi salah satu pihak dalam ketentuan kontraktuan liabilitas tersebut. Entitas menghentikan pengakuan liabilitas ketika liabilitas telah dilunasi dengan kas atau setara kas atau aset nonkas telah dibayarkan kepada pihak lain sebesar jumlah yang harus dibayarkan.

2 Pengukuran

Aset keuangan liabilitas diukur sebesar biaya perolehannya dan dicatat sebesar jumlah yang harus dibayarkan.

3 Penyajian

Entitas menyajikan liabilitas keuangan dalam kelompok liabilitas pada laporan posisi keuangan.

c. Ekuitas

1 Pengakuan

Ekuitas Skaters Shop Distro terdiri dari modal yang disetor oleh pemilik dana berupa kas dan saldo laba rugi yang diakui dalam pos ekuitas.

2 Pengukuran

Modal yang disetor dan saldo laba rugi dicatat sesuai dengan peraturan perundangan yang berlaku.

3 Penyajian

Modal yang disetor dan saldo laba rugi disajikan dalam kelompok ekuitas 
dalam laporan posisi keuangan.

3. Laporan Laba Rugi

a. Pendapatan

1 Pengakuan

Pendapatan diakui ketika terdapat hak atas pembayaran yang diterima atau yang masih harus diterima baik pada masa sekarang atau masa depan. Entitas mengakui pendapatan dari suatu penjualan barang atau penyediaan jasa ketika barang tersebut telah dijual atau jasa telah diberikan kepada pelanggan. Berdasarkan rekapitulasi pencatatan pemasukan kas pada Skaters Shop Distro, pendapatan yang diakui yaitu penjualan barang dagang kepada pelanggan dan diakui ke dalam pos pendapatan.

2 Pengukuran

Entitas mencatat pendapatan untuk manfaat ekonomik yang diterima atau yang masih harus diterima secara bruto. Dalam hal ini Skaters Shop Distro menjual barang dagang secara tunai sehingga mencatat pendapatan langsung ke pos pendapatan dan tidak melakukan pencatatan untuk pendapatan yang masih harus diterima.

3 Penyajian
Pendapatan disajikan di kelompok pendapatan dalam laporan laba rugi.

b. Beban

1 Pengakuan

Beban diakui dalam laporan laba rugi jika penurunan manfaat ekonomik dimasa depan yang berkaitan dengan penurunan aset atau kenaikan liabilitas telah terjadi dan dapat diukur secara andal. Berdasarkan laporan rekapitulasi pengeluaran kas pada Skaters Shop Distro beban angkut pembelian, beban transportasi pembelian, beban gaji dan upah, beban sewa toko, beban listrik air dan telepon, beban perbaikan dan perawatan, beban persediaan barang dagang, beban perlengkapan, beban penyusutan peralatan, dan beban lain- lain diakui ke dalam pos beban.

2 Pengukuran

Peneliti membuat dasar pengukuran beban yang digunakan dalam penyusunan laporan keuangan Skaters Shop Distro adalah biaya historis. Hal ini sudah ditetapkan oleh SAK EMKM. Pembayaran sewa diukur berdasarkan metode garis lurus selama masa sewa.

3 Penyajian

Beban disajikan dalam kelompok beban dalam 
laporan laba rugi. Skaters Shop Distro belum menyajikan pos pajak penghasilan dalam laporan laba rugi.

c. Laporan Laba Rugi

1. Pengakuan

$\begin{array}{lr}\begin{array}{l}\text { Laporan laba rugi } \\ \text { memasukkan }\end{array} & \begin{array}{r}\text { semua } \\ \text { penghasilan dan beban yang }\end{array} \\ \text { diakui dalam suatu periode, } \\ \text { kecuali SAK EMKM } \\ \text { mensyaratkan } \\ \text { Berdasarkan rekapitulasi } \\ \text { pencatatan pemasukan dan } \\ \text { pengeluaran kas Skaters } \\ \text { Shop Distro laba rugi } \\ \text { diakui sebagai laba rugi } \\ \text { sebelum pajak penghasilan. }\end{array}$

2. Pengukuran

Laba rugi sebelum pajak penghasilan diukur dari selisih dari pendapatan dan beban.

3. Penyajian

Laba rugi sebelum pajak penghasilan disajikan dalam laporan laba rugi. Laba rugi sebelum pajak penghasilan pada Skaters Shop Distro merupakan laba bruto karena belum dikurangkan dengan pajak Entitas Mikro, Kecil, dan Menengah (SAK EMKM). Laporan keuangan disajikan secara sistematis untuk menjelaskan secara naratif rincian jumlah yang disajikan dalam laporan keuangan dan pos-pos yang tidak memenuhi kriteria dalam pengakuan laporan keuangan. Skaters Shop Distro tidak menyusun catatan atas laporan keuangan dikarnakan penghasilan. Berdasarkan Peraturan Pemerintah Nomor 23 Tahun 2018 tentang Pajak Penghasilan atas penghasilan atas usaha yang diterima atau diperoleh Wajib Pajak yang memiliki Peredaran Bruto tertentu menyebutkan Wajib Pajak Orang Prbadi atau Wajib Pajak Badan tidak termaksuk bentuk Usaha Tetap menerima penghasilan dari usaha tidak termaksud penghasilan dari jasa sehubungan dengan pekerjaan bebas, dengan peredaran bruto tidak melebih Rp 4.800.000000 dalam setahun akan dikenakan tarif yang bersifat final sebesar $0,5 \%$ dari jumlah peredaran bruto setiap bulan.

2. Analisa Catatan Atas Laporan Keuangan Skaters Shop Distro Berdasarkan SAK EMKM.

Catatan atas laporan keuangan ini memberikan informasi tentang suatu pernyataan bahwa laporan keuangan telah sesuai dengan Standar Akuntansi Keuangan belum mengerti tentang informasi yang disajikan dalam catatan atas laporan keuangan. 
Tabel 4 Perbandingan Penerapan Akuntansi Skaters Shop Distro dengan Penerapan Akuntansi Berdasarkan SAK EMKM

\begin{tabular}{|c|c|c|c|c|}
\hline$N_{0}$ & Keterzggy & Seaunt S.AK E.MKMI & Jenunt Skaters Shop Diston & Kersugiar \\
\hline 1 & Prnglom & 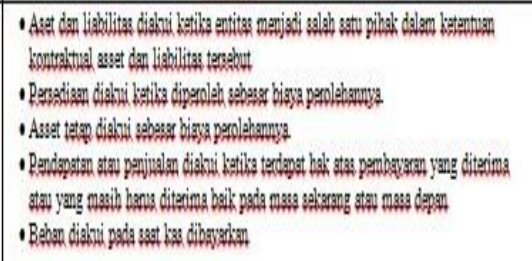 & 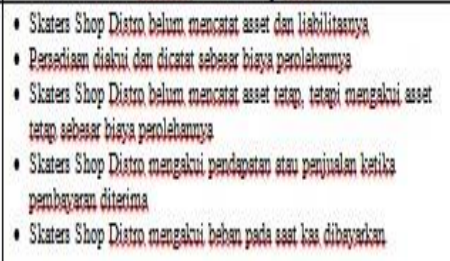 & 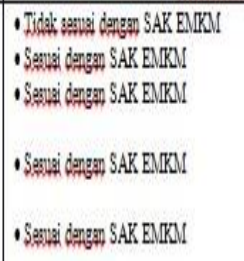 \\
\hline 2 & Pengiharan & 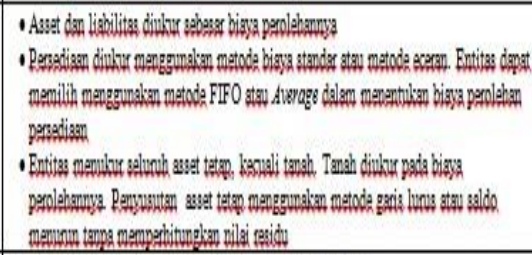 & 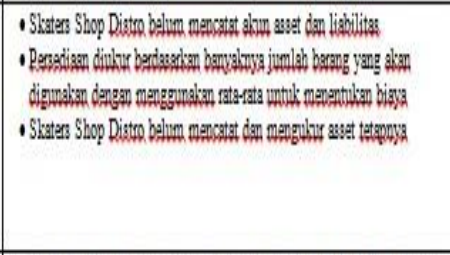 & 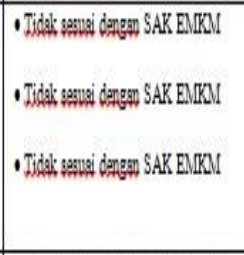 \\
\hline 3 & Penvioin & 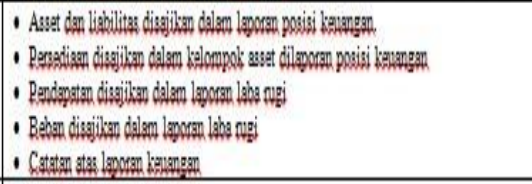 & 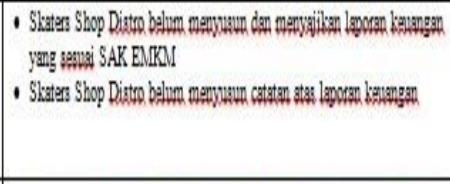 & 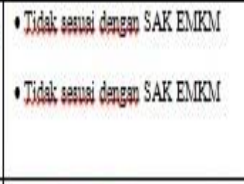 \\
\hline 4 & Pelexperan & 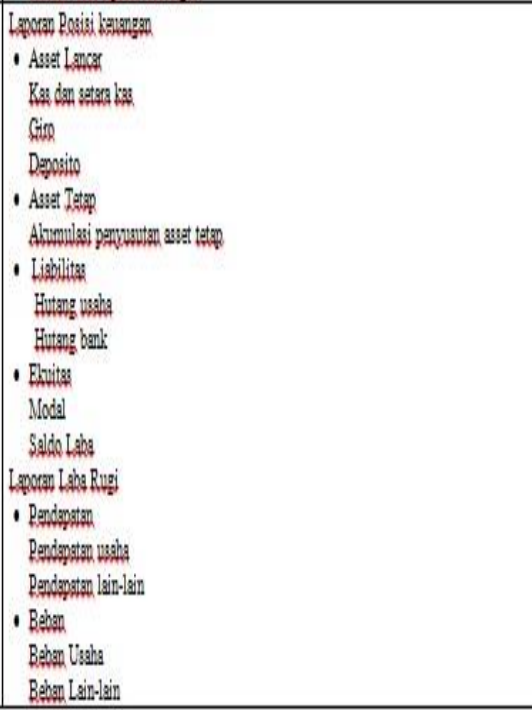 & 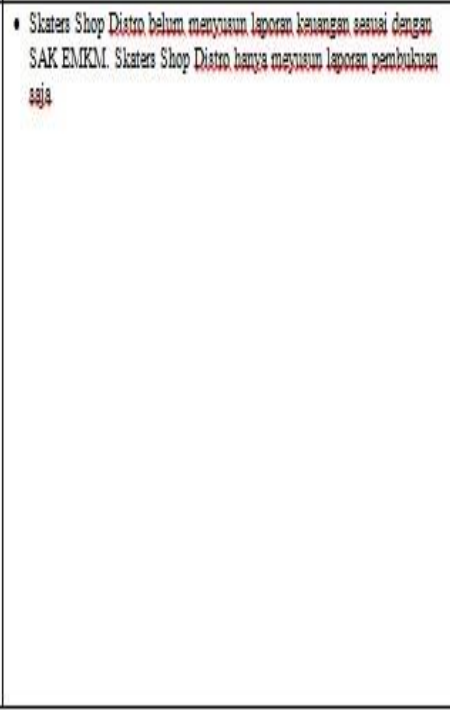 & 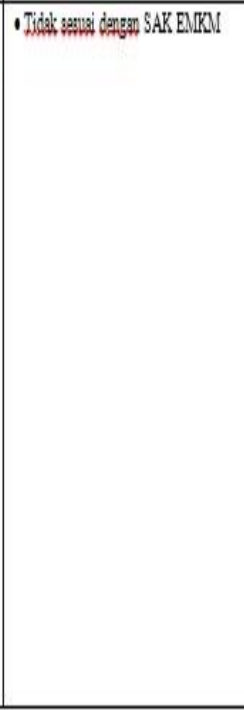 \\
\hline
\end{tabular}

Copyright (c) 2020 Tasum Tasum SE., M.Si

\section{cc) (†) (2)}

This work is licensed under a Creative Commons Attribution-NonCommercial-ShareAlike 4.0 International 


\section{KESIMPULAN DAN SARAN}

\section{Kesimpulan}

1. Berdasarkan pembahasan maka dapat penulis simpulkan bahwa, pemahaman pemilik Skaters Shop Distro tentang Standar Akuntansi Keuangan Entitas Mikro, Kecil, dan Menengah (SAK EMKM) masih sangat rendah. Pencatatan dan penyususnan laporan keuangan masih sangat sederhana dan sesuai kebutuhan dan pemahaman pemilik. Skaters Shop Distro belum menerapkan SAK EMKM karena masih belum memahami tentang SAK EMKM dan keterbatasan waktu serta sumber daya manusianya.

2. Kendala-kendala yang dihadapi oleh Skaters Shop Distro dalam menerapkan SAK EMKM, belum adanya tenaga akuntansi yang profesional pada Skaters Shop Distro. Pemilik menyadari pentingnya pencatatan dan penyususnan laporan keuangan hanya saja, belum memahami cara mencatat dan menyusun laporan keuangan yang sesuai SAK EMKM.

\section{Saran}

Berdasarkan kesimpulan hasil penelitian, maka penulis mengajukan saran bagi Skaters Shop Distro sebagai berikut :

1. Skaters Shop Distro hendaknya melakukan pencatatan, pembukuan, dan membuat laporan keuangan sesuai dengan Standar Akuntansi Keuangan Entitas Mikro, Kecil, dan Menengah (SAK EMKM) yaitu laporan posisi keuangan, laporan laba rugi, dan catatan atas laporan keuangan. Memperkerjakan minimal satu karyawan yang mempunyai keahlian dibidang akuntansi secara professional atau sebaiknya mengikuti pelatihan tentang penerapan SAK EMKM agar dapat meningkatkan kemampuan dan keterampilan dalan menyajikan laporan keuangan.

2. Skaters Shop Distro dalam melakukan pencatatan hendaknya lebih memeperhatikan aset-aset perusahaan, bukan hanya pada pendapatan dan beban saja. Selain mencatat dan membuat laporan pembukuan secara manual, sebaiknya juga mencatat dan membuat laporan pembukuannya menggunakan komputer karena hasilnya lebih akurat dan dapat dipahamai.

3. Dalam pembahasan diatas sudah dijelaskan dan berdasarkan data yang peniliti peroleh dari Skaters Shop Distro penulis telah membuat rekomendasi laporan keuangan Skaters Shop Distro yang sesuai berdasarkan SAK EMKM dapat dilihat pada lampiran. Sehingga rekomendasi tersebut bisa diterapkan dalam pembuatan laporan keuangan ditahun selanjutnya. 
Bahri, S. (2016) Pengantar Akuntansi. Yogyakarta: ANDI

Fitria, D. (2014). Buku Pintar Akuntansi Untuk Orang Awam dan Pemula Secara Otodidak. Jakarta: Laskar Aksara

Harahap, S, S. (2015). Teori Akuntansi. Jakarta: Rajawali Pers

Hery. (2013). Teori Akuntansi Suatu Pengantar. Jakarta: Lembaga penerbit Fakultas Ekonomi Universitas Indonesia

Hery. (2014) Akuntansi Dasar 1 dan 2. Jakarta: Grasindo

Hery. (2015). Akuntansi Dasar 1 dan 2. Jakarta: PT Grasindo

Hery. (2017). Teori Akuntansi (Pendekatan konsep dan analisis). Jakarta: PT Grasindo

Ikatan Akuntan Indonesia. (2017) Standar Akuntansi

Keuangan. Jakarta: Salemba Empat

Indonesia, I, A. (2016). Standar Akuntansi Keuangan Entitas Mikro, Kecil dan Menengah Efektif 1 Januari 2016. Jakarta: Ikatan Akuntan Indonesia

Indonesia, I, A. (2016). Standar Akuntansi Keuangan Entitas Tanpa Akuntabilitas Publik (SAK ETAP). (ONLINE), Retrieved from

\section{DAFTAR PUSTAKA}

http://iaiglobal.or.id/v03/stan dar -akuntansikeuangan/syariah.

Indonesia, I, A., (2018). Standar Akuntansi Keuangan. (ONLINE), Retrieved from http://iaiglobal.or.id/v03/stan dar-akuntansi-keuangan/sak

James, M, Reeve, D. (2013). Pengantar Akuntansi: Adaptasi Indonesia. Jakarta: Salemba Empat

Kasmir. (2016). Analisis Laporan Keuangan. Jakarta: Rajawali Pers.

Mubarok, H, W, Y, \& A. (2017) Kualitas Laporan Keuangan. Jakarta: Kencana

Nanang Shonhadji, Laely Aghe A, D. (2017). Penerapan Penyusunan Laporan Keuangan pada Usaha Kecil Menengah berdasarkan SAK EMKM di Surabaya

Nayla, A, P. (2014). Komplet Akuntansi untuk UKM dan Waralaba. Yogyakarta: Laksana.

Nurlaila. (2018). Penerapan Standar Akuntansi Keuangan Entitas Mikro Kecil dan Menengah (SAK EMKM) pada Sukma Cipta Ceram Ic D inoyo - Malang.

Purnamasari, U. (2018). Penyusunan Laporan Keuangan pada Perusahaan Dagang berbasis SAK EMKM pada Usaha Dagang Deni Distro. 
Putra, I, M. (2017). Pengantar Akuntansi. Yogyakarta: Quadrant.

Rizal, E. (2013). Accounting Principles: Prinsip-prinsip Akuntansi Berbasis SAK ETAP, Jakarta: PT Raja Grafindo Persada.

Sadeli, H, L, M. (2015). DasarDasar Akuntansi. Jakarta: Bumi Askara.

Sadeli, H, Lili, M. (2014). Dasardasar Akuntansi. Jakarta: Remaja Rosdakarya.

Seoliana, M. (2015). Pengantar Akuntansi 2. Jakarta: Prenada Media.

Setyawan, D, D. (2018). Rancangan Penerapan Standar akuntansi Keuangan (SAK) Entitas, Mikro, Kecil, dan Menengah (EMKM) "So Kressh" Di Kecamatan Blimbing Kota Malang.

Sugiyono. (2013). Metodologi Penelitian Kuantatif Kualitatif dan $R \& D$. Bandung: Alfabeta.

Sugiyono. (2016). Metodologi Penelitian Kuantatif Kualitatif dan $R \& D$. Bandung: Alfabeta.

Sujarweni, V, W. (2017). Analisis Laporan Keuangan. Yogyakarta: Pustaka Baru Press.

Susanto, A. (2013). Sistem Informasi Akuntansi. Bandung: Lingga Jaya.

Triati, N. (2013). Pengantar Akuntansi. Jakarta: PT Indeks Undang-Undang Republik Indonesia. (2008). Nomor 20 Tahun 2008 Usaha Mikro
Kecil dan Menengah. (ONLINE), Retrieved from, https://www.bi.go.id/id/tenta ng-bi/uu-bi/Documents/UU 20Tahun2008UMKM.pdf

V, Wiratna, S. (2016). Pengantar Akuntansi. Yogyakarta: Press, Pustaka Baru

Wahyudiono, B. (2014). Mudah Membaca Laporan Keuangan. Jakarta: Raih Asa Sukses

Wardiya, M, L. (2017). Analisis Laporan Keuangan. Bandung: CV Pustaka Setia

Copyright (c) 2020 Tasum Tasum SE., M.Si 


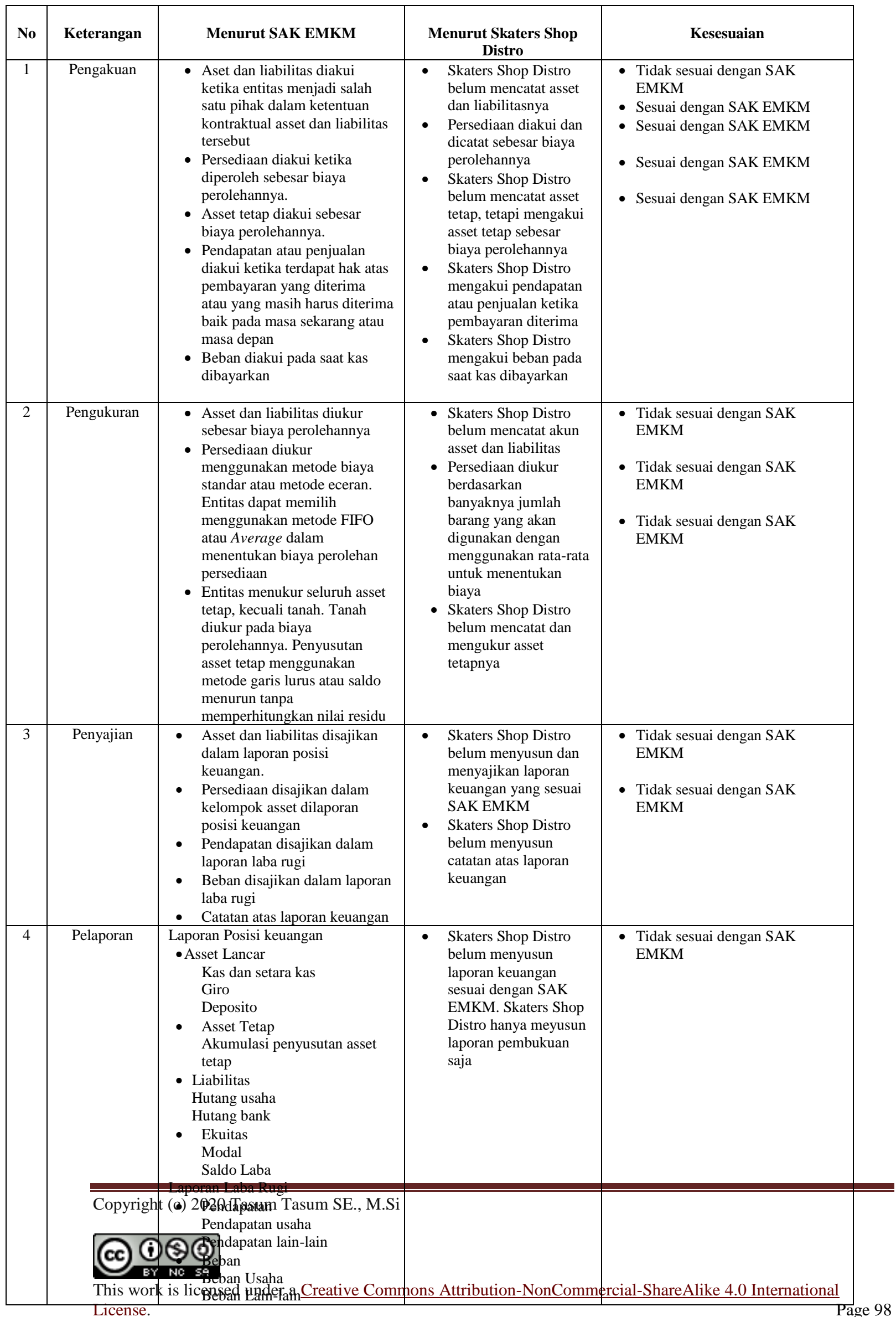




\section{Lampiran :}

Copyright (c) 2020 Tasum Tasum SE., M.Si

\section{(-) $(100$}

This work is licensed under a Creative Commons Attribution-NonCommercial-ShareAlike 4.0 International License. 